\title{
Comparing Dermestes maculatus (DeGeer) infestation of cured tropical freshwater fishes [Oreochromis niloticus (Linnaeus) and Clarias gariepinus (Burchell)]
}

\author{
Davies Ibienebo Chris ${ }^{1}$, Ebere Samuel Erondu ${ }^{1,}$,, Usman Zakka², Nenibarini Zabbey ${ }^{1}$ \\ ${ }^{1}$ University of Port Harcourt, Faculty of Agriculture, Department of Fisheries, Choba, Rivers State, Nigeria \\ ${ }^{2}$ University of Port Harcourt, Faculty of Agriculture, Department of Crop and Soil Science, Choba, Rivers State, Nigeria
}

\section{Email address:}

ebere.erondu@uniport.edu.ng (Erondu E. S.), eserondu@yahoo.com (Erondu E. S.)

\section{To cite this article:}

Davies Ibienebo Chris, Ebere Samuel Erondu, Usman Zakka, Nenibarini Zabbey. Comparing Dermestes maculatus (DeGeer) Infestation of Cured Tropical Freshwater Fishes [Oreochromis niloticus (Linnaeus) and Clarias gariepinus (Burchell)]. Agriculture, Forestry and Fisheries. Vol. 3, No. 5, 2014, pp. 434-438. doi: 10.11648/j.aff.20140305.27

\begin{abstract}
A multiple choice test was used to determine the rate of infestation of $D$. maculatus on two cured fish species of commercial importance. All the treatments had three replicates and were arranged in randomized complete block design. The infested and non-infested dried fish were subjected to a taste panel of four to evaluate the texture and taste quality of the fish before and after infestation. Percentage weight loss of the fish was also determined 30 days post infestation. A skewed $32 \%$ weight loss in C. gariepinus compared with $24.4 \%$ in $O$. niloticus was recorded. The study revealed that D. maculatus infestation rate (number of adults and larvae per fish specimen) was more in C. gariepinus than O. niloticus. Quality (taste and texture) damage was significantly greater in $C$. gariepinus than $O$. niloticus $(\mathrm{p}<0.05)$. The study also reveals that the entomofauna may feed on any material that has animal steroids. The effect of the pest infestation is discussed in the context of taste and texture characteristics, substrate fragmentation and frass weight. There is imperative need to develop appropriate pro-poor control measures which will minimize economic losses due to D. maculatus infestation of stored fish and fish products in the tropics.
\end{abstract}

Keywords: Dermestes maculatus, Cured Fish, Oreochromis niloticus, Clarias gariepinus, Freshwater Fish

\section{Introduction}

Fish is one of the cheapest animal protein sources consumed over millennia and it is being used increasingly to correct protein deficiency in diets in the tropics [1]. In Africa, where animal protein is scarce and expensive, with average intake considered low, cured fish, is used to increase household protein intake [2] since, it is comparable, if not a better, source of protein. Essuman [3] reported declining fish consumption in West Africa over the last decade. This stems from the inability of the production sector to meet the soaring demand of an ever increasing population, coupled with the demand-supply gap created by post-harvest losses.

FAO [4] reported that cured fish can suffer considerable loss of weight due to feeding damage caused by insect pest. Up to $50 \%$ loss can result due to beetle infestation over several months. From processing throughout storage shelflife, fish is vulnerable to insect pests belonging to 3 families, namely, Calliphoridea, Sarcophagidae (blowflies) and Dermestidea (beetle) [5, 6]. Dermestes maculatus is cosmopolitan and the most preponderant insect pest of dried fish in sub-Saharan Africa [6,7]. Pest damage can cause fragmentation of cured fish; and this can lead to quantitative loss of the smaller fragments and loss of value due to quality reduction, visual quality loss due to contamination by live or dead pests, or by their cast skins and frass. Lale et al. [8] estimated 20 - 50\% deterioration of smoked fish products during storage arising from microbial and insects' pest infestation in the tropics. More so, Esser et al. [9] put physical and financial losses in Indonesia at between 10 and $50 \%$ and 25 and $90 \%$, respectively, for the fish species they investigated. Huss [10] stated that reduction in post harvest losses could add another 20-30 million tonnes in the cured fish sector.

Insects infest cured fish during and after processing, especially in the tropics and subtropics. D. maculatus occurs widely in stored produce especially those of animal origin, 
but the species infestation and damage to dried fish has not been studied in sufficient detail. This study was aimed at investigating under controlled conditions, D. maculatus infestation load and associated losses of two cured fish species of commercial importance in the Niger Delta, Nigeria, namely, Clarias gariepinus and Oreochromis niloticus. It is envisaged that the result would provide valuable information that will guide the development of appropriate control measures for hide beetle infestation of cured fish.

\section{Materials and Methods}

Fish species and processing: Samples of two commercially important and highly relished fish species, $O$. niloticus and C. gariepunus were bought from Choba market, Rivers State, Nigeria and smoked using a local smoking kiln. The fishes were arranged on drying tray (chicken wire mesh) placed over an open-air smoking kiln. Clean fresh plantain leaves were used to cover the fish on the tray to enhance smoke circulation and drying.

Sterilization of jar and insect culture: All the jars used were subjected to thermal sterilization. Larvae of $D$. maculatus were obtained from heavily infested dried fish bought from the same market and kept in 1-L culture jar and allowed to develop on smoked fish substrates in the laboratory. The emerging pupae were removed and placed individually in a clean plastic tube and held under laboratory conditions until metamorphosed adults D. maculatus emerged using the methods described in Zakka et al. [11] and Akinwumi [1].

Multiple Choice and Selective tests: To determine the relative rate of infestation of both fish species by $D$. maculatus, multiple-choice test was carried out. In test $\mathrm{F}$, a sample of cured $C$. gariepinus and $O$. niloticus were kept separately each in two clean Kilner jars and placed horizontally with their open ends facing a centrally located Petri-dish containing 10 pairs of D. maculatus. This enabled the beetles to have uninterrupted access to the cues from both fish samples. In test B, the two clean Kilner jars having separately the fish samples were placed horizontally with their closed ends facing the beetle stocked Petri-dish so as to obscure the attractive odour emanating from the different fish species. Each treatment had three replicates and these were arranged in randomized complete block design. At the end of the 30 days experiment, the fish specimens in the multiplechoice test were dissected and D. maculatus (larvae and adults) were isolated and counted.

Determination of physical characteristics of fish samples Moisture content: The moisture contents of the exposed fish samples were determined before and at the end of the experiment. The sample of fish was dried in an oven at a temperature of $60{ }^{\circ} \mathrm{C}$ for one hour and the weight of water lost calculated [11].

Texture and taste: Infested and non-infested fish were subjected to organoleptic taste. A panel of four (4) people was constituted to evaluate the texture and taste of the fish.

The texture and taste of the fish samples was evaluated using the following model in Table 1:

Table 1. Taste and textural quality ranking model

\begin{tabular}{llll}
\hline Texture & & Taste & \\
\hline Quality & Score & Quality & Score \\
\hline Firm & 3 & Good & 3 \\
Fairly firm & 2 & Acceptable & 2 \\
Brittle & 1 & Poor & 1 \\
Powdery & 0 & Unacceptable & 0 \\
\hline
\end{tabular}

Weight loss: Percentage weight loss was determined by direct weighing method in which the initial and final weights of each fish substrate were recorded and the percent weight loss calculated [12].

Percentage Economic fish loss was calculated as

$$
\% \text { loss }=\frac{(\mathrm{W} 1-\mathrm{W} 2) \mathrm{g} \times 100}{\text { cost price of individual fish }}
$$

Where W1 is the initial weight of each fish sample, and W2 is the final weight of the fish after infestation.

\section{Results}

Table 2 shows the rate of infestation by adults and larvae of D. maculatus on the cured fishes. The T-test analysis shows significant difference between the number of adult beetles $/ 100 \mathrm{~g}$ of $O$. niloticus in both treatments. However, the result shows no significant difference $(\mathrm{P}>0.05)$ between the number of larvae $/ 100 \mathrm{~g}$ of $O$. niloticus in both treatments $(\mathrm{F}$ and $\mathrm{B}$ ) and the combinations. The result of the rate of infestation by D. maculatus on C. gariepinus is also shown in the same table. The T-test analysis shows that the number of adult beetles $/ 100 \mathrm{~g}$ of $C$. gariepinus in both treatment $\mathrm{F}$ and $\mathrm{B}$ varied $(\mathrm{P}<0.05)$ but did not vary between the number of larvae $/ 100 \mathrm{~g}$ of cured C. gariepinus.

Table 2. Rate of infestation of adult and larvae of D. maculatus on cured fish (O. niloticus and C. gariepinus)

\begin{tabular}{lll}
\hline Fish species/treatment & $\begin{array}{l}\text { No. of Adult/100g } \\
\text { of fish sample }\end{array}$ & $\begin{array}{l}\text { No. of Larvae/100g } \\
\text { of fish sample }\end{array}$ \\
\hline $\begin{array}{l}\text { O. niloticus }(\mathrm{F}) \\
\text { O. niloticus }(\mathrm{B})\end{array}$ & 21.19 & 38.11 \\
C. gariepinus (F) & 19.69 & 20.32 \\
C. gariepinus (B) & 15 & 58 \\
t-value & 3 & 17 \\
$\mathrm{P}(\mathrm{T}<=$ t) two-tail & 6.93 & 1.08 \\
$*$ t-value & 0.02 & 0.39 \\
$* \mathrm{P}(\mathrm{T}<=\mathrm{t})$ two-tail & 13 & 1.88 \\
\hline
\end{tabular}

(F) = cured fish kept horizontally with their open ends facing a centrally placed petri dish containing10 pairs of $D$. maculatus.

(B) $=$ cured fish kept horizontally with their closed ends facing $D$. maculatus stocked in Petri dish; to interfere with cues emanating from the different fish species.

Table 3 shows the percentage weight loss of the fish species at the end of the experiment due to insect activity. The T-test result shows that there was no significant difference between the percentage weight loss and frass weight in $O$. niloticus in both treatments $\mathrm{F}$ and $\mathrm{B}(\mathrm{P}>0.05)$ 
(Figure 1). By contrast, the result shows significant difference between \%weight loss in $C$. gariepinus in treatment $\mathrm{F}$ and $\mathrm{B}(\mathrm{P}>0.05)$ (Figure 2). The \% frass weight caused by $D$. maculatus feeding activities was not significant in $C$. gariepinus between treatment $\mathrm{F}$ and $\mathrm{B}(\mathrm{P}>0.05)$.

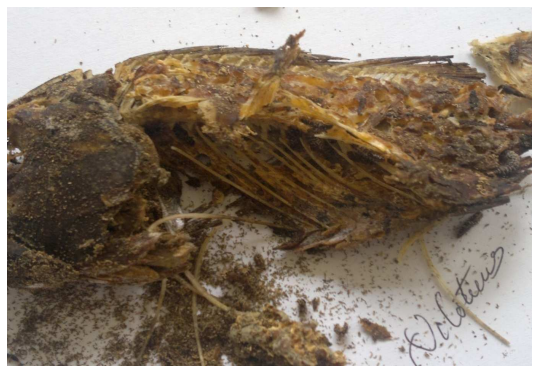

Figure 1. Frass and remnant of $O$. niloticus sample; and larvae of $D$. maculatus post infestation.

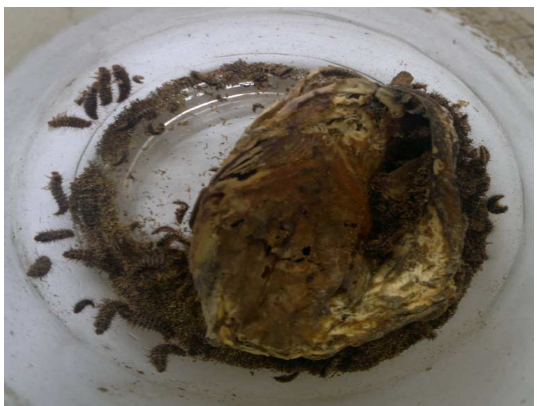

Figure 2. Frass and remnant of C. gariepinus sample; and larvae of D. maculatus post infestation.

Table 3. Percentage weight loss of fish specimens and \% frass weight of samples of $O$. niloticus and $C$. gariepinus infested by D. maculatus

\begin{tabular}{lll}
\hline Fish species/treatment & \% weight loss & \% frass weight \\
\hline O. niloticus $(\mathrm{F})$ & 24.42 & 11.54 \\
O. niloticus $(\mathrm{B})$ & 16.52 & 9.76 \\
C. gariepinus (F) & $31.81^{\mathrm{a}}$ & 20.87 \\
C. gariepinus (B) & $18.91^{\mathrm{b}}$ & 11.84 \\
$\mathrm{t}$-value & 1.21 & 0.44 \\
$\mathrm{P}(\mathrm{T}<=\mathrm{t})$ two-tail & 0.35 & 0.701 \\
$* \mathrm{t}-\mathrm{value}$ & 3.88 & 1.87 \\
$* \mathrm{P}(\mathrm{T}<=\mathrm{t})$ two-tail & 0.060 & 0.20 \\
\hline
\end{tabular}

${ }^{\mathrm{a}-\mathrm{b}}$ in the same column are significantly different; $(\mathrm{F})=$ exposed fish samples in containers kept horizontally with their open ends facing a centrally placed Petri-dish containing 10 pairs of D. maculatus.

(B) = exposed fish samples in containers kept horizontally with their closed ends facing the Petri-dish so as to reduce interference of cues emanating from different fish species.
Table 4 shows mean values recorded for texture and taste of the infested fish samples. The values recorded for $O$. niloticus were 2.25 and 2.63 for taste and texture, respectively. In contrast, $C$. gariepinus had 1.1 and 1.3 for taste and texture, respectively. The results also indicate that while infested $O$. niloticus were still fairly firm, $C$. gariepinus samples were brittle and considerably fragmented. The taste value shows that $O$. niloticus was still in acceptable edible state while $C$. gariepinus had a poor taste.

Table 4. Quality (Texture and Taste) of fish samples (O. niloticus and $C$. gariepinus) infested with D. maculatus

\begin{tabular}{lll}
\hline Fish species/treatment & Taste & Texture \\
\hline O. niloticus & 2.25 & 2.63 \\
C. gariepinus & 1.1 & 1.3 \\
\hline
\end{tabular}

Table 5 indicates a negative correlation between the number of adult beetle and weight loss of the fish species $(r=$ -0.038). Also a negative relationship was calculated between the texture of the fish species and weight loss of the fish species. A highly significant value was observed between the $\%$ weight loss of the fish species and the weight loss of the fish species $\left(r=0.945^{* *}\right)$. The texture of the fish species and the weight loss were negatively correlated with high significance $(\mathrm{P}<0.01)$. A negative correlation was observed between the \%weight loss of the fish species and the number of adult $(\mathrm{r}=-0.150)$. A high correlation was observed between frass weight and the number of larvae $(r=0.754)$ and the correlation was highly significantly $(\mathrm{P}<0.01)$. Negative relationship was observed between texture of the fish and the number of larvae found in the fish species $(r=-0.499)$. The correlation was high and positively significant $(\mathrm{P}<0.05)$ between the $\%$ weight loss and frass weight $\left(0.687^{*}\right)$. Also, a negative correlation was recorded between texture and frass weight of the fish species. The texture and the \% weight loss of the fish species were negatively correlated. Negative value was also observed between the texture, taste and the \% weight loss of the fish species.

Table 6 shows the economic losses due to infestation of the different fish species caused by $D$. maculatus. The estimated loss in Nigerian naira per kilogramme of infested fish was $\# 253.60 \mathrm{k}$ for $C$. gariepinus and \#204.70k for O. niloticus, representing $25.36 \%$ and $20.47 \%$ losses, respectively.

Table 5. Correlation coefficient matrix showing the interrelationship between the Indices (weight losses, number of adult beetle, number of larvae, frass weight, \% weight loss, taste and texture of the fish species)

\begin{tabular}{|c|c|c|c|c|c|c|}
\hline & Wt Loss & No. Of Adults & No. Of Larvae & Frass Wt & $\% W t$ loss & Texture After \\
\hline \multicolumn{7}{|l|}{ Wt Loss } \\
\hline No. Of Adults & -0.033 & & & & & \\
\hline No. Of Larvae & 0.329 & 0.180 & & & & \\
\hline$\% \mathrm{Wt}$ loss & $0.945 * *$ & -0.150 & 0.524 & $0.687^{*}$ & & \\
\hline Texture After & -0.018 & 0.075 & -0.499 & $-0.628 *$ & -0.392 & \\
\hline
\end{tabular}

** Correlation is significant at the 0.01 level (2-tailed)

* Correlation is significant at the 0.05 level (2-tailed) 
Table 6. Economic losses due to D. maculatus infestation of C. gariepinus and O. niloticus.

\begin{tabular}{lllll}
\hline Fish species & \%weight loss of fish sample & Estimated loss/kg of infested fish(g) & Cost (\#) & Estimated loss/kg of infested fish (\#) \\
\hline C. gariepinus & 25.36 & 253.6 & 1000 & 253.6 \\
O. niloticus & 20.47 & 204.7 & 800 & 204.7 \\
\hline
\end{tabular}

\section{Discussion}

The study revealed that cured fresh fish kept in jars placed with their open ends facing each other had more larvae of $D$. maculatus thus suggesting that the beetle could preferentially select suitable substrate even when cues from different substrates abound [11,13]. According to Corbet [14], the ability to select chemical cues is passed from the larval stage to the adult. These cues trigger recognition of a substrate and so influence selection by the adult. C. gariepinus proved to be a more suitable substrate for $D$. maculatus development. Zakka et al. [15] reported that $C$. gariepinus flesh was a more preferred substrate for $D$. maculatus infestation than $O$. niloticus. This suggests superiority in nutritional composition as $D$. maculatus larvae prefer substrates with high lipid content [16].

The high weight loss in C. gariepinus (32\%) and $24.4 \%$ in $O$. niloticus after 30 days infestation is at variance with the findings of Golob et al. [17] who recorded 19\% dry weight and $12 \%$ on wet weight basis, in stored fish. The weight loss incurred could partly be due to the differences in length of the experiment, fish type and other factors. Awoyemi [18] assessed fish loss and reported that by 60 days the exposed fishes were reduced to mere frass and bones. It could be explained that the higher weight loss suffered by C. gariepinus was due to higher level of infestation (that is higher number of larvae). Traditionally cured fish are capable of sustaining significant losses, both in quality and value. This is because both the adult and larvae feed on infested fish samples, causing large quantitative losses of edible material, and there is also fragmentation of the remaining product $[19,20]$.

D. maculatus feeds on any material that has animal steroids $[12,21]$. However, when exposed to various animal steroid sources the insect tends to show preference to a particular species. The comparatively high weight loss, detectable change in taste and significantly higher frass generated in $C$. gariepinus samples suggest the species flesh was a more suitable substrate than $O$. niloticus for the growth and development of D. maculatus. Zakka et al. [15] and Zakka et al. [11] observed that $C$. gariepinus had the highest suitability index, while Lale et al. [8] also recorded high infestation levels on C. gariepinus than on Tilapia sp.

Generally, the results may not be linked to the positioning of the fish samples or chemical cue emanating from them because there were little or non-significant difference between most of the treatments. It is plausible that protein and lipid contents are the key infestation determinants. According to Samish et al. [16], D. maculatus prefers diets higher in lipid and protein content, which would be unsaturated for other insect. Osuji [22] screened 30 samples for the presence of insect pests in four fish species (Clarias $s p$, Citharinus sp, Heterotis $s p$, and Synodontis $s p$ ) and found that the infestation load correlated to the lipid content of the fishes. Clarias sp with a mean of 82 individual insects per $100 \mathrm{~g}$ (lipid content $16.4 \%$ ) had significantly higher number of insect pests. It is known that $D$. maculatus develops more effectively on fish with higher fat contents.

Based on the number of adult D. maculatus that emerged from the fish substrates, C. gariepinus proved to be a more suitable substrate. Nevertheless, the high infestation rate (number of adults and larvae) of D. maculatus in both fish species is an indication that the insect constitutes serious threat to stored fish products $[18,23]$.

The present study showed a considerable loss of both fish substrates leading to fragmentation and loss of quality. This is attributable to extensive feeding habit of $D$. maculatus on fish substrates and the presence of the exuvia [24]. Atijegbe [25] evaluated quality loss during storage, noting that damage severity may be partly a function of moisture and the lipid contents of the fish at the time of storage. The $25 \%$ weight loss recorded compares favourably with previous records. Lale and Sastawa [8], Odeyemi [24], and Atijegbe, [25] assessed the value and extent of quantitative losses of different fish species and reported 50-100\% quantitative and qualitative losses depending on storage length, salt content and climatic conditions. From the variables assessed, $C$. gariepinus is a more suitable substrate for D. maculatus development than O. niloticus, and overall, D. maculatus infestation can lead to quantum loss in both commercially important freshwater fishes.

\section{References}

[1] Akinwumi, F.O (2011). Evaluation of some plant materials for the control of smoked fish pest, Dermestes maculatus DeGeer (Coleoptera: Dermestidae) in Clarias gariepinus Burchell(Pisces: Claridae) ARPN Journal of Agricultural and Biological Science 6(7) : 65-69

[2] Akinwumi, F.O., Fasakin, E.A. and Adedire, C.O. (2006). Progeny inhibiting effects of four plant products against the Leather beetle and Copra beetle on smoked African mudfish. Journal of Biological Sciences 6(6): 1023-1028

[3] Essuman, K.M. (2005). The role of Inland Fish in Food consumption in West Africa: A review and annex Artisanal fish containers in Ghana. A Case study. http:/www.fao. org/ documents/005/T0606B/T0606B05.htm.

[4] FAO, (2002). Workshop on promotion of sustainable commercial aquaculture in Zambia and Malawi, Lusaka, Zambia, 2-4 October 2002

[5] Sastawa, B. M. and Lale, N. E. S. (1998). Effects of spatial and temporal variation on the population of the skin beetle $(D$. maculatus. DeGeer) infesting smoked dried African cat fish (Clarias gariepinus) in a depot in Maiduguri (Nigeria) and implication for its management. ESN Occasional Publication $31 ; 259-256$. 
[6] Johnson, C. and Esser, J. (2000). A review of insect infestation of traditionally cured fish in the tropics. Department for International Development, London. 92pp.

[7] Dobie, P., Haines, C.P., Hodges, R.J., Prevet, P.F. and Rees, D.P. (1991). Insects and Arachnids of Tropical Stored Products. Their Biology and Identification (Kent. Uk: Natural Resources Institute) 246Pp.

[8] Lale, N. E.S., Ajayi, F. A. and Sastawa, B.M. (2000) Evaluation of processing methods and insectistatic essential oils for the control of skin beetles (Dermestes maculatus, DeGeer) infesting dried fish in the Lake Chad district of Nigeria. Appl.Trop.Agric. 5:(2) 135-143.

[9] Esser, J. R. S. Sunarya and Wiryante, J. (1989). Assessment and reduction of insect infestation of cured fish in Indonesia, A case study. Post Harvest Technology, Preservation and Quality of fish in South East Asia 149-157

[10] Huss, H. H (1988). Fresh fish quality and quantity change. A training manual prepared for the FAO/DANIDA training programme on fish technology and quality control. FAO Fisheries series No. 29, FAO/DANIDA Rome, 1988. pp.65-71.

[11] Zakka, U., Ayertey, J.N. and Cobblah, M.A (2009). Suitability of four smoked fish species to Dermestes maculatus DeGeer, (Coleoptera: Dermestidae) Nigerian Journal of Entomology, 26:35-39

[12] Lale, N.E.S. (2002). Stored Products Entomology and Acarology inTropical Africa. $1^{\text {st }}$ Edition, Mole pub. (Nig) Ltd Maiduguri, $204 \mathrm{pp}$

[13] Zakka U.(2005). Development of Dermestes maculatus DeGeer (Coleoptera: Dermestidae) on different fish substrates. Mphil. Thesis in Entomology University of Ghana, 128pp

[14] Corbet, S. A. (1985). Insect chemosensory responses: a chemical legacy hypothesis. Ecological Entomology, 10: 143 -153 .

[15] Zakka, U., Ayertey, J.N. and Cobblah, M.A (2013). Development of Dermestes maculatus (DeGeer, 1774) (Coleoptera: Dermestidae) on different fish substrates. Jordan Journal of Biological Science 6(1)5-10
[16] Samish, M., Argaman, Q., and Perelman, D. (1992). Research notes: The hide beetle D. maculatus Deg (Dermestidae), feeds on live turkey. Poultry Sci.71:388-390

[17] Golob, P., Gueye-N'Diaye, A. and Johnson, S. (1995). Evolution of some pyrethroid and organophosphate insecticides as protectants of stored dried fish. Tropical Science 35:76-92.

[18] Awoyemi, M. D. (1991). Some experiments on the control of pest of dried fish in Kainji Lake. In: National Institute of Fresh Water Fisheries Research, 1998, Annual report, New Bussa, Nigeria $110-118 \mathrm{pp}$

[19] FAO (1989). A field guide to the type of insect and mites infesting cure fish. Fisheries Technical Paper No.303. Food and Agriculture Organization of the united nations, Rome. (Handbook)

[20] Johnson, C. and Esser, J. (2000). A review of insect infestation of traditional cured fish in the tropics. Department for International Development, London. 92p

[21] Mound, L. (Ed) (1989). Common Insects of Stored Food Products. A Guide to Their Identification. $7^{\text {th }}$ Edition, British Museum (Natural History) Economic series NO. 15.

[22] Osuji, F.N.C (1974). Beetle infestation in dried fish in relation to infestation by Dermestes maculatus (Coleoptera, Dermestidae) and N. Rufipes (Coleoptera, Cleridae). Journal of west African Science Association 19:131-136

[23] Don-Pedro, K.N. (1989). Mechanisms of action of some vegetable oils against Sitophilus zeamais Motschulky, (Coleoptera: Curculionidae) on wheat. Journal of Stored Product Research, 24 (40: 217-223.

[24] Odeyemi, O.O., Owoade, R.A. and Akinkurolere, O. (2000). Toxicity and population suppression effects of Parkia clappatoniana on dried fish pests (Dermestes maculatus and Necrobia rufipes). Global Journal of Pure and Applied Sciences 6:191-195.

[25] Atijegbe, S.R. (2004). Infestation of smoked fish in Ghana. Mphil. Thesis in Entomology University of Ghana, 103pp 